I N T ER N ATIONAL MONETARY FUND

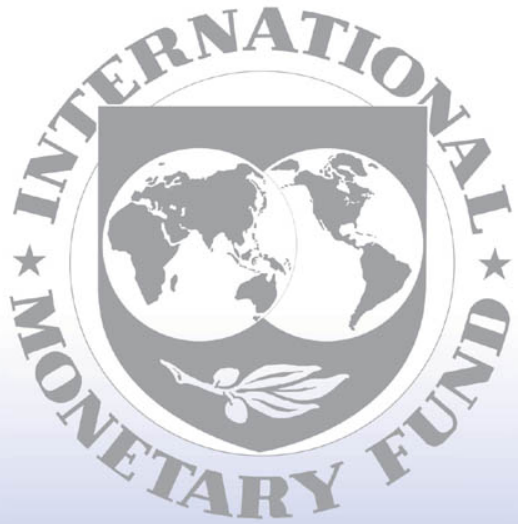

Staff

Country

Reports 


\title{
Hungary: Report on the Observance of Standards and Codes—Data Module and Fiscal Transparency-Updates
}

\begin{abstract}
These Updates to the Report on the Observance of Standards and Codes on Data Module and Fiscal Transparency for Hungary were prepared by a staff team of the International Monetary Fund as background documentation for the periodic consultation with the member country. They are based on the information available at the time they were completed on May 7, 2002. The views expressed in these documents are those of the staff team and do not necessarily reflect the views of the government of Hungary or the Executive Board of the IMF.
\end{abstract}

The policy of publication of staff reports and other documents by the IMF allows for the deletion of market-sensitive information.

To assist the IMF in evaluating the publication policy, reader comments are invited and may be sent by e-mail to Publicationpolicy@imf.org.

Copies of this report are available to the public from International Monetary Fund 3 Publication Services 700 19th Street, N.W. 3 Washington, D.C. 20431

Telephone: (202) 62374303 Telefax: (202) 6237201 E-mail: publications@imf.org 3 Internet: http://www.imf.org

International Monetary Fund Washington, D.C. 


\section{REPORT oN THE OBSERVANCE OF STANDARDS AND CODES \\ HUNGARY-DATA MODLLE: AN UPDATE MAY2002}

This note provides a factual report on developments in data dissemination since the Report on the Observance of Standards and Codes was released in May 2001. For a full description ofinstitutions andpractices, it should be read in conjunction with the original report. ${ }^{1}$

\section{Hungary continues to observe the Special Data Dissemination Standard (SDDS) specifications for the coverage, periodicity, and timeliness of all data categories, including the detailed template on international reserves and foreign currency liquidity, and for the dissemination of advance release calendars. The authorities have also addressed a number of issues of data quality noted in last year's report:}

\section{National Accounts}

- $\quad$ Progress been made in the project to revise the data on imputed rents, currently extrapolated from 1993 data, on the basis of more up-to-date survey data. The Hungarian Central Statistical Office (HCSO) conducted a pilot survey in 1999, representing the first collection of market rents. Following the next survey, likely to be held in late 2002 or early 2003, the HCSO will calculate a new benchmark. The revision of the national accounts to incorporate the new calculation of imputed rents would probably be done in 2003 , with a base year of 2000 , taking into account the 2001 population census.

- $\quad$ The HCSO has continued to systematically disseminate the statistical discrepancy between the final version of GDP by production activities and GDP by expenditure components in its national accounts publications. The HCSO first published the statistical discrepancy in July 2001 in its publication Statistical National Accounts Hungary 1998-99. The series is updated on an annual basis, and only in the final accounts. Hence, the July 2002 publication will continue this practice and update the series by one year, i.e., through 2000 .

- $\quad$ Significant progress has been made regarding the development of seasonally-adjusted quarterly national accounts estimates. A new unit has been established within the HCSO responsible for statistical methodology. Its first task has been to work on seasonal adjustment, not only of the national accounts estimates but also of other short-term data series. Its choice has been to use the TRAMO seasonal adjustment program. On this basis, seasonally-adjusted quarterly national accounts statistics will

${ }^{1}$ The original report is entitled Hungary: Report on the Observance of Standards and Codes-DataModule (SM/O1/142,5/3/01) and is available on the IMF web site at http://www.imforg/external/np/rosc/rosc asp. 
be published beginning in June 2002 for the first quarter of 2002 (and, retrospectively, beginning from Q1 1996) with base year 1995.

\section{Monetary Statistics}

- $\quad$ The value of deposits of a credit institution in the process of liquidation is now zero. Thus, monetary aggregates Ml through M4 do not include any deposits of credit institutions under liquidation. In the future, this kind of deposit will be excluded from monetary aggregates and will be shown under "restricted deposits." However, the national definition of the monetary base does still include deposits of some credit institutions in the process ofliquidation. This problem will be solved in the first half of 2002.

- The incorrect sectorization of nonprofit institutions was resolved in May 2001, with the introduction of the new reporting forms using the sectorization of the System of National Accounts (SNA93). In addition, on the basis of the new reports, the National Bank of Hungary $(\mathrm{NBH})$ has produced comparable time series from the beginning of 2000 .

- Beginning in May 2001, depository corporations have been required to report securities on the asset side of their balance sheets at market prices (net of loss in value), and no longer at acquisition prices. Comparable time series for these data have been calculated from the beginning of 2000 .

\section{Balance of Payments Statistics}

- $\quad$ Strengthened institutional cooperation between the NBH and the HCSO, covering methodological and technical issues, aims at replacing current International Transactions Reporting System (ITRS) goods data by customs statistics and incorporating reinvested earnings in foreign direct investment. Introducing accrual accounting for investment income also has high priority for the NBH. These steps, which are planned to be first introduced for the 2002 annual data (to be published in early 2003), will place the balance of payments statistics and Hungary's international investment position on an internationally comparable basis. Replacing the ITRS data by customs data will also bring the valuation of financial leasing and the classification of goods for processing and repairs in line with the IMF's Balance of Payments Manual (Fifth Edition - BPM5). 


\section{Government Finance Statistics}

- $\quad$ Problems remain within government finance statistics, especially reflecting the growing size of off-budget activities. ${ }^{2}$

- The government budget is prepared in line with the Government Finance Statistics (GFS86), as required by the Act on Public Finances (APF). However, significant progress has been made in compiling government finance statistics on a European System of National Accounts (ESA95) basis, which is the basis for the fiscal notifications by EU member states to Eurostat and which also underlies the medium-term fiscal projections included in Hungary's Pre-accession Economic Program. Following the finalization of the 2001 budgetary accounts, Hungary intends to publish the ESA95-based estimates. An amendment to the APF, effective January 1,2002 , requires all economic units engaged in quasi-fiscal activities to report regularly to the Ministry of Finance. Adopting ESA95 as the standard for budget preparation and presentation is under consideration. Enhanced monitoring, and the accrual concept underlying ESA95, will help reconcile some of the differences between the national accounts and the government finance statistics.

\section{Staff Commentary}

Progress has been made in further improving Hungary's economic statistics. Hungary complies with the SDDS in all its dimensions. The base metadata and summary methodologies underlying the Hungarian economic statistics have been regularly updated on the Dissemination Standards Bulletin Board (DSBB). Significant progress has been made in addressing several data quality issues regarding national accounts statistics and monetary statistics. The current work underway to place the balance of payments statistics on an accrual basis will bring them fully in line with international best practice by early 2003 . However, while work is underway to improve fiscal accounting, the coverage of published government finance statistics remains incomplete.

${ }^{2}$ See Hungary: Report on the Observance of Standards and Codes--Fiscal Transparency (SM/01/115,4/20/01) and Fiscal Transparency: An Update (May 2002). 


\section{REPORT oN THE OBSERVANCE OF STANDARDS AND CODES \\ HUNGARY - FISCAL TRANSPARENCY: AN UPDATE \\ MAY 2002}

This note provides afactual report on developments infiscal transparency since the Report on the Observance of Standards and Codes was released in April 2001. For afull description of institutions and practices, it should be read in conjunction with the original report. ${ }^{1}$

The 2001 report on fiscal transparency concluded that Hungary had made significant progress in increasing the transparency and accountability of government in recent years and met many of the requirements of the Code of Good Practices on Fiscal Transparency. At the same time, it identified several areas in which further progress could be made. The following is a summary of developments over the past year:

- Significant fiscal activities are still conducted outside the purview of the Ministry of Finance. A number of the activities of the Hungarian Privatization and State Holding Company (APV Rt) and the Hungarian Development Bank (MFB) are of a fiscal nature and remain outside of the scope of the government budget ${ }^{2}$ In 2001, the amount of spending outside of the government budget increased and is estimated at about $1 \frac{1 / 2}{2}$ percent of GDP, the bulk of which is accounted for by the National Motorway Company, a subsidiary of the MFB.

- The Government has initiated steps to monitor off-budget fiscal activities. The Act on Public Finance (APF) was amended in late 2001 to include detailed reporting requirements for all economic units engaged in fiscal activities, including public trust funds, public non-profit companies, the APV Rt, and the MFB and its subsidiaries. ${ }^{3}$

1 The original report is entitled Hungary: Report on the Observance ofStandards and Codes-Fiscal Transparency (SM/01/115,4/20/01), and is available on the IMF web site at http//www.imforg/external/np/rosc/rosc.asp.

${ }^{2}$ However, the Budget Law submitted to Parliament contains an annex on the APV Rt with projections of its expenditures related to state assets.

${ }^{3}$ Effective January 1, 2002, the APV Rt is required to submit a monthly report on cash receipts and expenditures covering the transactions to/from the privatization reserve and monitoring the stock of cash and deposits, lt is also required to provide the same "Quarterly Balance Sheet Report" as the budgetary units, covering the aggregates of the assets and liabilities and a breakdown of the change in stocks due to cash and non-cash transactions, revaluation, and other volume changes. The MFB and its subsidiaries are required to submit quarterly data. Finally, most of the other economic units will be required to report on a annual basis, although more frequent reporting can be requested if needed. 
- There is partial reporting of quasi-fiscal activities. The Ministry of Finance does not prepare a regular, comprehensive report of all quasi-fiscal activities. However, while tax expenditures are not monitored systematically, tax credits granted against personal income tax and corporate income tax are computed by the Ministry of Finance and included in the budget documentation. Also, the State Aid Monitoring Office (SAMO) is required to prepare an annual report, which includes an estimate of the value of tax concessions provided. Its latest report, covering 1999-2001, was published in April 2002.

- A new reporting system on the value of financial assets of the state is under preparation. Currently, reports on financial assets prepared by budgetary units are compiled largely at historical cost valuation. A government decree, effective January 2002, introduces a new accounting and reporting system for budgetary units, which allows for the re-valuation of financial assets to reflect market prices. The Ministry of Finance intends to compile quarterly accounts on the valuation of state financial assets, and publish quarterly stock data (in coordination with the National Bank of Hungary, which intends to publish financial accounts for all sectors of the economy on a quarterly basis).

- $\quad$ The State Audit Office has completed its review of public procurement. The report was published in May 2001. ${ }^{4}$

- The Ministry of Finance has published the macroeconomic model underlying its macro-fiscal forecasts. The model was presented in the Statistical Review of Hungary 2001.

\section{Staff Commentary}

Fiscal transparency falls short of international best practice. Off-budget spending, primarily by the Hungarian Development Bank and its subsidiaries, has increased over the past year. The amendment of the Act on Public Finance requiring all off-budget spending units to report such spending regularly to the Ministry of Finance is welcome. However, compliance with the new requirements has been uneven so far. Looking ahead, the objective should be to integrate all the fiscal activities of institutions currently outside of the scope of the government budget into the regular budgetary process. Amending the legal basis of the current system of fiscal accounts may require some time. The first priority should therefore be to ensure that all off-budget spending is reported in a timely and comprehensive manner to the Ministry of Finance and reflected in its public reports, including the next government budget, its final annual report to Parliament, and its regular monthly monitoring reports.

\footnotetext{
${ }^{4}$ The report is available on its web site http:/www.asz.gov.hul.
} 